\title{
STUDY ON SOCIAL ENTREPRENEURSHIP IN ROMANIA
}

\author{
Silvia STROESCU ${ }^{*}$, Vlad-Andrei PORUMB ${ }^{2}$ \\ ${ }^{1}$ National University of Physical Education and Sport, Faculty of Physical Education and Sport, Bucharest, \\ Romania \\ ${ }^{2}$ Faculty of Economics and Business, University of Groningen, Netherlands \\ *Corresponding author: stroescusilvia@yahoo.com
}

DOI: https://doi.org/10.51267/icpesk2020bp13

\begin{abstract}
Entrepreneurship represents the process of creating added value by committing the necessary time and effort while taking financial, psychological and social risks. Successful entrepreneurship suggests an approach to creation - the creation of something modern and profitable at the same time. The value is provided by the utility of the product or service offered to both the entrepreneur and the clients. Unlike the traditional entrepreneurship framework, social entrepreneurs are fundamentally seeking to produce "social esteem" instead of benefits, their work pursuing long-term poverty alleviation. Because the field of entrepreneurship is still emerging in Romania, businessmen often face barriers such as the ambiguities in the legislative system or lack of financial resources. We therefore decided to carry out a detailed study of what social entrepreneurship means in the Romanian setting and provide answers to some of the key questions that may lead to developing this market. Our study will have an essential educational role in proving that the business model is best suited to improving, for example, the living conditions of the marginalised, as well as reducing the number of socially assisted people and turning them into active actors in the labour market. Social enterprises are likely to put increasing pressure on the market to achieve social change, which we consider beneficial for society.
\end{abstract}

Keywords: entrepreneurship, social entrepreneurship, Romanian setting

\section{Introduction}

Entrepreneurship represents the process of creating added value by committing the necessary time and effort while taking financial, psychological and social risks. Moreover, entrepreneurship suggests an approach to creation - the creation of something that is new and profitable at the same time. The esteem is given by the utility of the item or benefit advertised to both the entrepreneur and the clients.

The point of rise and activation of entrepreneurial behaviour is an imaginative thought. A business visionary is the one who distinguishes a trade opportunity and makes an organization capitalise on that opportunity. According to Herron and Robinson (1993), an initial model of the "entrepreneurial characteristics" relationship must include the mediating role of motivation and the moderating role of entrepreneurial management abilities.

Social entrepreneurs aim to find innovative solutions to the greatest challenges of society: social, cultural, economic or environmental - they can be recognised in all areas of movement and all callings (i.e. instruction, pharmaceuticals, design, social exercise, trade, administration, horticulture, etc.).

The substance of social business enterprise is to seek the advancement of living conditions and provide opportunities for disadvantaged or vulnerable people. Businesses need to be innovative and have a positive impact on those involved, the community and disadvantaged groups (people with disabilities or very low incomes). On the other hand, the social enterprise can be a form of business enterprise in which the "social enterprise" is established to illuminate 
social issues and put the reinvestment of benefit on the bleeding edge. Social entrepreneurship represents the entrepreneurs' initiatives and should not be confused with corporate social responsibility (CSR), which is about supervising a business. Companies that are socially dependable take into consideration the interface of several clusters: representatives, providers, collaborators, the nearby community and the nation in general. The objective of CSR is not so much the benefit as the positive picture, reputation, trust, lasting connections with all the variables with which the company comes into contact. The CSR and social entrepreneurship concepts have numerous things in common, but the major distinction comes from the level of decision-making. Scholars are beginning to contribute to the development of this new discipline through efforts that attempt to trace the emergence of social entrepreneurship as well as by comparing it to other organizational activities such as conventional entrepreneurship (Dacin et al., 2011).

Unlike traditional entrepreneurship, social entrepreneurs seek primarily to generate "social value" rather than profits, their work pursuing long-term poverty alleviation. This does not exclude the desire to make profit, but it is often reinvested or shared among members, or it helps the community in one way or another.

This approach also comes with challenges, because many entrepreneurs pursue personal goals, some of which are noneconomic in nature. Thus, decisions about whether to found ventures, about how vigorously to grow them, or about whether or not to close down marginal businesses are all influenced by the personal values of entrepreneurs. (Cooper, 1993)

\section{Purpose of study}

Because the field of entrepreneurship is still emerging in Romania, businessmen often face barriers such as the ambiguities in the legislative system or lack of financial resources. We therefore decided to carry out a detailed study of what social entrepreneurship means and provide answers to some of the key questions that may lead to developing this market. Also, we advance a conceptual proposal, which is the result of wider research on the phenomenon of social entrepreneurship in a clear, rigorous way that allows the reader to take a closer look at the concept, familiarise themselves with the concept and identify its influence on the current state of affairs via a brief reading of the text (Light, 2011).

\section{Methodology}

As research methods, we use an extensive theoretical review from where we highlight the importance of social entrepreneurship in a society with many shortcomings. All the theoretical data that we have used in this article present various studies conducted over several years and make a thorough analysis of opportunities for the development of social entrepreneurship in Romania. 


\section{Main Findings}

\section{Starting from social entrepreneurship and the three pillars}

According to Amponsah-Tawiah (2013), social entrepreneurship needs three defining elements: (1) People - the ability of your business to change people's lives and develop sustainable communities; (2) Planet - the impact of your business on the environment. Does your business contribute to a healthier planet or directly affect it? (3) Profit - as any ordinary business, social entrepreneurship must have a profit in order to pay employees and grow.

Find a product and a mission for it!

The mission is very important in social entrepreneurship but it is not more important than the product sold. A social enterprise needs a steady stream of cash-flows in order to grow. For example, LSTN Sound is a company that sells premium audio headphones, and part of its revenue goes to the Starkey Hearing Foundation, which helps people with hearing impairments.

Another example of social entrepreneurship is Love Your Melon in the United States, which sells hoops, and $50 \%$ of the profit goes to a foundation that studies cancer in children. It also has programmes to mobilise students, its primary buyers, to participate in helping patients.

Define your mission and illustrate the impact!

Mission represents a competitive advantage of any social business. You can sell the same product as a competitor, but you have the emotional advantage. Donating to causes is not the only way to make social entrepreneurship, but they are even more complex.

Reduce your footprint on the Planet by using sustainable products and non-polluting methods. You can organize personal development and social entrepreneurial events that highlight the benefits of this business and lifestyle, but also bring people in need of help to possible donors.

According to Rawhouser et al. (2019), social entrepreneurship literature has focused on understanding the characteristics of individual social entrepreneurs, focusing on their noble intentions (Miller et al., 2012), goals, identities and values (Stevens et al., 2015) or the missions of their associated organizations (Dacin et al., 2011). These studies often assume that organizations that claim to address social problems (e.g. reducing poverty, reducing illiteracy) are more likely to achieve these missions or are more compassionate and well intentioned (Miller et al., 2012) than traditional market-focused organizations.

\section{Create an inclusive and diverse work environment!}

Unlike other types of business, transparency is very important in social entrepreneurship to maintain customer confidence and not to hurt the mission.

\section{Financing social entrepreneurship}

Obviously, the enterprise can be funded from simple donations, yet it is best to build a business selling products around it. For example, in Romania, "Made in Roșia Montană" wool socks are an example of successful social business. The business creates socks of wool with the inhabitants of Roșia Montană, and part of the profit goes to them, which helps them to live better in the absence of golden exploitation that would endanger the environment. 
Another good method are crowdfunding sites, which react well to projects that have very interesting products but also a social cause.

Benefits that social entrepreneurs generate in communities where they work:

- Increasing the number of employed people - Social entrepreneurship creates jobs and opportunities. At the same time, employment or training opportunities are created for disadvantaged categories or become a link between the labour market and the unemployed;

- Innovation and creation of new services for social needs that are not included by society - Social problems most often addressed by social enterprises at this time are: HIV/ AIDS, people with disabilities, illiteracy, drug abuse, etc.

- Creating social capital to support sustainable social and economic development.

Social entrepreneurship is not just for directors of companies with dozens of employees. Even start-up entrepreneurs can take some socially positive measures. They can improve or, in case of success, even transform problems related to health, education, social exclusion or poverty. Regardless of the profile of a contractor, a team of a social enterprise is important to include diverse people from the NGO, corporate, creative area and to have a diversity of ages and experiences. Diversity and exposure generate innovation, a key ingredient in social entrepreneurship.

Here are some ways in which society can benefit from entrepreneurs who also have a social mission:

Social entrepreneurship can have a positive effect through a firm's hiring policy. Such an entrepreneur can propose to offer a career start to social categories that the rest of entrepreneurs hesitate to employ. Of course, this depends on the company: it can be people with disabilities, former convicts, people discriminated against on the basis of ethnicity, race or religion, or simply the elderly. For example, a handicraft bakery in Australia offers jobs exclusively to refugees and people in need of asylum and profit is reinvested in training and staff development efforts, as The Guardian reports (Restrepo, 2016).

\section{Supporting education}

Companies can contribute to the development of school programme and education in very diverse ways. First, a social entrepreneur can propose to hire people without qualifications and invest a few months in their professional training. Second, companies can get involved in young talent financing projects, such as the payment of university studies or the costs of students and students who are distinguished in certain areas. Last but not least, another positive impact that a company can have in education is to equip educational institutions, such as by acquiring computers or teaching materials. However, as businesspeople are actively involved in such projects, the first step is to recognise the value of education. Education should not be equated solely with business, as it is a broader, deeper and richer concept. (Jones \& Iredale, 2010) In the study conducted by Ilhan Ertuna and Gurel (2011), findings suggest that students with higher education have a higher intention of becoming entrepreneurs. 


\section{Products and services useful to the company}

The part of a trade is to meet request for items and administrations, but a business visionary with a social mission goes advance than that. This can be illustrated by entrepreneurs advertising items that fathom squeezing social problems. For example, there are currently several companies that support the expansion of the electricity grid using affordable solar panels. It is estimated that 2 billion individuals around the world do not have power, either because it does not reach them or because of its high cost in relation to their revenues. In Africa, millions of people utilise lamp fuel lights that are not as it were perilous but moreover destructive to health. Some socially-oriented businesses sell affordable solar panels to limit the use of these lamps, leading to about one million deaths annually around the world, according to The Guardian (Meaker, 2016).

\section{Supporting charitable foundations}

A few companies choose that, for each item that clients purchase, they make a small donation. For example, there are companies that donate a pair of shoes for each pair of shoes bought, as is the case for the One for One campaign at Toms, according to Entrepreneur. Whether it is a foundation that is associated with the company or whether it is working with an existing one, the social impact is positive. For society, such actions of companies result in stronger and more organized nongovernmental organizations that can intervene more effectively in tackling serious social problems.

\section{In Romania}

In Romania, the field is at the beginning, and businessmen often face barriers such as the ambiguities in the legislative system or lack of financial resources. A study demonstrates that this difficult context does not discourage them, but rather motivates social entrepreneurs to be energetic and creative, to search for solutions and resources on their own, to overcome the barriers that arise in their way.

Social entrepreneurship is framed as an activity in the sphere of social economy, along with other forms through which it manifests its presence in Romania. This has ended up in a progressively curious concept for both NGOs and the trade environment, being a specialised concept. People have understood that change comes first when they decide to put their shoulders to work and change something for the better in their communities.

Young Romanians come with many bold ideas with a social impact, but they need guidance and help to develop a sustainable business model around their idea. Also, businesspeople are starting to be curious about the social effect of their investments and are getting included within the pro-bono mentoring of social undertakings.

How does social entrepreneurship develop in Romania?

Although in recent years social entrepreneurship has become a more talked-about concept, there are still few initiatives in this area, the development being just at the beginning.

There is now more uncertainty, supposedly social entrepreneurship is reported where it is not and there is confusion with charity or economic areas that do not actually have social goals. 
Social entrepreneurship has been discussed for some time in Romania but, being not a priority and being misunderstood as a resource consumer, has not expanded too much. A factor that has contributed to its slow development was the resistance of Romanians to associative structures, which reminds them of the forced associations imposed by the communists. This is also the explanation for which the social economy in all its forms is strongly developed in Europe, higher growth being recorded in France.

How does the social entrepreneurship ecosystem look in Romania?

- Social entrepreneurship in Romania is at an early stage. It is often described as ambiguous or even vulnerable, partly due to the lack of a legal framework;

- It enjoys a lot of untapped potential - a great variety of ideas, challenges, causes of social problems;

- It is fragmented due to the lack of functional networks between initiatives and their retention. Currently, there are no strong networks promoting social innovation.

\section{Social innovation map}

Geographically, Bucharest is perceived as the most developed area with the greatest potential in Romania. It is followed by some major cities: Cluj, Iași, Timișoara. Rural areas are much less developed but are also bidding for social business development due to the lack of infrastructure. The north-western, western and urban areas of Romania are significantly more developed than the rest of the country.

Ashoka (Romanian-American Foundation, 2017) is the largest global organization to promote and support social entrepreneurship and social innovation and has created the Map of Social Innovators in Romania, which includes the 932 leading innovators in the field. The map outlines how entrepreneurs from different social fields relate and helps us understand the environment in which they work.

The social entrepreneurship environment in Romania is made up of 53\% women and $47 \%$ men, being the only such ecosystem in Europe where women are more numerous than men. $17 \%$ of innovators work in social inclusion, $17 \%$ in socio-economic development, $16 \%$ in education, $15 \%$ in civic engagement, $14 \%$ in cross-cutting areas and $7 \%$ in healthcare. (Ionescu-Heroiu, 2018)

Why is social entrepreneurship important now in Romania?

Damaschin-T,ecu (Pascaru \& Doboș, 2012) answers this question by saying that they have chosen developing countries with emerging markets where to support the development of social enterprises because they are the most sought after and have a huge power to use community resources to solve community issues in a sustainable way.

The reason is that emerging markets (and Romania is no exception) are characterised by the existence of sources of financing, but which are insecure, fluctuating and dependent. In this context, in order to get back to the question, social enterprises come to do long-term work that creates long-term jobs - wherever they are most needed and where social problems are the most serious.

What are the problems that social entrepreneurship in Romania is currently facing?

The main problems faced by a social business are related to the lack of technical assistance (both before starting the business and after its implementation) and the difficulty of accessing appropriate and necessary funds to start it and survive until the profitability threshold is 
reached. These aspects, overlapped with a weak entrepreneurial culture, perpetuate the inertia and the idea that "we cannot".

Of course, there are other issues related to the legislative environment, the bureaucracy that social entrepreneurs have to fight, whether or not socially, or the absence of a coherent national movement (for example, there is the Social Enterprise Alliance in the US, and the Social Enterprise Coalition in the UK). But things are becoming more and more dynamic in this area in Romania too, where more and more people and organizations are interested in the potential of social enterprises to solve critical social problems, which is encouraging.

Several sources of funding and examples of social entrepreneurship

According to Ionescu-Heroiu (2018), 55\% of Romanian social entrepreneurs are limited by the lack of funding opportunities.

The second biggest challenge for social innovators in Romania is the lack of a favourable legislative framework ( $31 \%$ of entrepreneurs), while $20 \%$ consider the lack of knowledge and experience in measuring social impact as a main obstacle. Many entrepreneurs who engage in social entrepreneurship at the community level partially or fully rely on regional and national sources of funding. These sources of funding, removed from the community and concerned with more systemic effects, may require more in the objective measurement of social value, given their low interaction with the social entrepreneur and reduced attention to impact within a specific community (Smith \& Stevens 2010).

However, social entrepreneurs are optimistic, creative and aware of the need to innovate.

Among the causes that have led to the expansion of the concept of social enterprise are dismissal and unemployment caused by financial crises.

One of the foremost vital trends in social entrepreneurship in Romania is that an increasing number of companies and financiers have been willing in recent years to provide money and support to social enterprises. One of the financiers is NESsT Romania, which offers $\$ 10,000$ and advice on the business of social enterprises owned and administered by NGOs.

One of the businesses funded by NESsT is "Sacoșa de Pânză" (the Canvas Bag) where several types of cotton bags are made. Approximately 9,500 bags have been made so far. There are six people in difficulty who carry out their activity in the workshop. Three of the six are physically disabled and work from home. The other three positions are for people whose main objective is the reintegration into the free labour market. They are employed in a workshop coordinated in partnership with the "Workshop without Borders" ("Ateliere fără Frontiere") Association. So far, two people have been integrated into the labour market and will be followed by a third. After a month of practical training, these people work to the standard in canvas bags.

Another financier is "Motivation", which offers personalised wheelchairs and independent living services to people with disabilities and has a status of protected unit. "Motivation" has 14 employees, five of whom are disabled.

The company started with the production of customised wheelchairs, then continued with their distribution and diversified its offer of printing services, facilitating the employment of people with disabilities. At present, the company produces 1,000 personalised wheelchairs annually.

According to the statistics of the General Directorate for the Protection of Persons with Disabilities, on 31.03 .2019 , 826,197 people with physical disabilities were registered in 
Romania, out of which 65,731 were children. Every year, over 5,000 people in Romania need a wheelchair to move around.

\section{Other sources of funding}

Eligible beneficiaries are NGOs, public institutions dealing with disadvantaged people, credit, consumer and production cooperatives, trade unions, employers, social economy companies and service providers for the disadvantaged.

EU funding has prompted many social actors to get involved in promoting and developing this concept in Romania, but unfortunately, often in a charitable way, not towards sustainability and the market, says Damaschin-Țecu (Pascaru \& Doboș, 2012).

Executive Director of Integra Romania estimates a strong increase in social entrepreneurship in the next five to ten years due to the influence and support of the European Union through its funding programmes. Thus, a trend in social entrepreneurship will be the spread of country-level initiatives. The most impactful social entrepreneurship initiatives can be easily started by local communities that now have problems and can find solutions.

Anyway, social entrepreneurship can be more prominent if it is state-supported by granting tax facilitation and encouraging transnational partnerships, because there will be an exchange of models of good practice in the field.

Who does social entrepreneurship in Romania?

At present, the most important player in local social entrepreneurship is represented by NGOs. In recent years, with the accession of our country to the European Union, many foreign donors have withdrawn, so the funding sources of NGOs have diminished.

In Romania, social enterprises run by NGOs can be set up as Limited Liability Companies, whose sole associate is the NGO or as an activity within that organization (in this case, from an accounting point of view, the activity of the company's social status is monitored separately from the current social projects of the organization).

The Authorised Protected Entity (UPA) is the self-managed (open or private) financial administrator where at least $30 \%$ of employees with a work contract are disabled. Such a unit is exempt from the payment of authorisation fees upon the establishment and reauthorisation and payment of corporate income tax (provided that at least $75 \%$ of the fund obtained through the exemption is reinvested for restructuring or the purchase of technological equipment, machinery, work equipment and/or the provision of sheltered workplaces).

How are social entrepreneurs in Romania?

- Social entrepreneurs are people who find innovative solutions to the greatest challenges of society: social, cultural, economic or environmental.

- Are enthusiastic about the opportunity to experience;

- Strongly emphasise research and testing;

- Are aware that the change they generate has a long-term impact and visible results in the distant future;

- Show solidarity and are open to exchanges of experience.

However, they are frustrated by the existing legislative framework, which is considered inefficient or even restrictive (missing important provisions), the lack of state support (financial, legislative), the restrictive agendas of some donors and the challenge of European funding that is perceived as misused, lacking coherence or continuity. 
Social entrepreneurship in a field such as civic involvement is a carousel that makes you dizzy but also enthusiastic. The biggest challenge, beyond finding the necessary financial resources, is to find the right balance between acting as Breaking News as a firefighter and working on seated programmes. But we feed on the enthusiasm of young people's reactions to civic education projects and the growing number of citizens who are eager to get involved.

What forms of social entrepreneurship exist in Romania?

Besides the companies launched by NGOs and/or authorised protected entities (UPA), other forms of social entrepreneurship are co-operative, the mutual aid house, the professional association, etc.

The Romanian legislation regulates a number of other forms that can be assimilated to the social economy, but which do not fully respect the principles enshrined in the European Charter of Social Economy principles. Depending on the characteristics of the social economy activities, they can be considered as forms of social economy and enterprises - microenterprises (SMEs), commercial companies and non-banking financial institutions (NBFIs).

The fields of action of social entrepreneurship are those with activities without a high degree of specialisation and which can be carried out in an associative structure: handicraft products, small production and various services (recycling, IT \& C services, jewellery, interior design products, gardening, fruit growing, jams, tourism, baby products, etc.).

For example, the services provided by UPA Winner are IT and web design, professional training, document management, document preparation and work safety consulting, transport, catering, tourism, marketing of several types of products (assembling of computers and laptops, prints, wicker wraps, glass icons and decorative art, etc.).

This unit was set up in 2007 by the Romanian Society of Locomotor Handicaps founded in 1990, with three employees, all with severe disabilities. The winner has approximately 170 clients, companies, or public organizations.

What are the main directions to which social entrepreneurship in Romania will go in the coming years?

The social enterprise will put more and more pressure on the market for social change. It will also have an essential educational role and will prove that the business model is best suited to improving, for example, the living conditions of the marginalised, reducing the number of socially assisted people and turning them into active actors in the labour market.

This means savings to the state budget and potential to increase the number of jobs in the country. The Ministry of Labour and SME Agencies are interested in the topic and are trying to regulate the field.

Buyers are increasingly concerned with the origin and composition of the items they expand and the way in which those involved in the production are treated. Universities have begun to study the phenomenon, traditional financiers are looking for market-oriented approaches in the social programmes that they support (for example, the Romanian-American Foundation pilots the granting of loans to NGOs) and financial specialists are more and more concerned with the social effect of their speculations. Numerous effective business visionaries are progressively inquisitive about locks in the pro-bono mentoring of social enterprises. A complete environment is about to be created in Romania around social ventures, which leads not only to financial improvement but also to social and cultural development. 


\section{Conclusion}

The defining purpose of social entrepreneurship, regardless of the financial model, is to make social changes by altering everyday social, economic and political realities at the local level. It is therefore the local context that shapes opportunities for social entrepreneurship and determines the strategies and tactics used. These strategies and tactics reflect an entrepreneurial approach to action characterised first by resourcefulness, second, by the ability to recombine resources into new value-creating configurations ('bricolage' of material, institutional and cultural resources) and finally by creation and innovation, i.e. new ways of doing things (Mair, 2010).

A social enterprise can be set up by anyone, starting with people in companies and reaching out to students as long as the emphasis is on the social mission. But social enterprises, especially at the start-up stage, have to cope with many risks, both economic and social. They need long-term, adequate, flexible support - for the time being, the Romanian state is not in a position to offer it.

Social enterprises are not yet defined in Romania and the phrase is used differently depending on the degree of understanding of each, suggesting the use of a social economy enterprise or a social economy entity.

We hope that Romania will follow this trend in a constructive way without entering into a game of strict and restrictive definitions, which risks losing innovative approaches outside the legal framework.

\section{Authors' Contributions}

Both authors have equally contributed to this study and should be considered as main authors.

\section{Acknowledgement}

This research was conducted as part of the project "Athletes becoming social entrepreneurs! Developing a gamification-based social entrepreneurship training program for athletes" (Erasmus+ Sport, project number 603312-EPP-1-2018-1-NO-SPO-SCP).

\section{References}

Amponsah-Tawiah, K. (2013). Occupational health and safety and sustainable development in Ghana. International Journal of Business Administration, 4(2), 74-78. https://doi.org/10.5430/ijba.v4n2p74

Cooper, A. C. (1993). Challenges in predicting new firm performance. Journal of Business Venturing, 8(3), 241-253. https://doi.org/10.1016/0883-9026(93)90030-9

Dacin, M. T., Dacin, P. A., \& Tracey, P. (2011). Social entrepreneurship: A critique and future directions. Organization Science, 22(5), 1203-1213. https://doi.org/10.1287/orsc. 1100.0620

Herron, L., \& Robinson Jr, R. B. (1993). A structural model of the effects of entrepreneurial characteristics on venture performance. Journal of Business Venturing, 8(3), 281-294. https://doi.org/10.1016/0883-9026(93)90032-Z 
Ilhan Ertuna, Z., \& Gurel, E. (2011). The moderating role of higher education on entrepreneurship. Education + Training, 53(5), 387-402. https://doi.org/10.1108/00400911111147703

Ionescu-Heroiu, R. (2018, March 29). 55\% dintre antreprenorii din România sunt limitați de lipsa oportunităților de finanțare [55\% of Romanian entrepreneurs are limited by the lack of funding opportunities]. Capital.

https://www.capital.ro/55-dintre-antreprenorii-din-romania-sunt-limitati-de-lipsaoport.html

Jones, B. \& Iredale, N. (2010). Enterprise education as pedagogy. Education + Training, 52(1), 7-19. https://doi.org/10.1108/00400911011017654

Light, P. C. (2011). The search for social entrepreneurship. Strategic Direction, 27(6). https://doi.org/10.1108/sd.2011.05627fae.001

Mair, J. (2010). Social entrepreneurship: Taking stock and looking ahead. IESE Business School, University of Navarra. Working paper no. WP-888. https://dx.doi.org/10.2139/ssrn.1729642

Meaker, M. (2016, March 1). The developing world faces a silent killer. Could a \$1 solar light help? The Guardian.

https://www.theguardian.com/sustainable-business/2016/mar/01/silent-killer-kerosene-airpollution-solar-liter-of-light-india-pakistan-philippines

Miller, T. L., Grimes, M. G., McMullen, J. S., \& Vogus, T. J. (2012). Venturing for others with heart and head: How compassion encourages social entrepreneurship. Academy of Management Review, 37(4), 616-640. https://doi.org/10.5465/amr.2010.0456

Pascaru, Gh., \& Doboș, A. (2012). Interviu cu Roxana Damaschin-Ţecu, Enterprise Development Director la NESsT Europe [Interview with Roxana Damaschin-Tुecu, Enterprise Development Director at NESsT Europe]. Revista de Economie Socială, 2(1), 137-143.

http://profitpentruoameni.ro/wp-content/uploads/2013/05/05-Interviu-cu-RoxanaDamaschin-Tecu-enterprise-development-director-la-NESST-Europe.pdf

Rawhouser, H., Cummings, M., \& Newbert, S. L. (2019). Social impact measurement: Current approaches and future directions for social entrepreneurship research. Entrepreneurship Theory and Practice, 43(1), 82-115. https://doi.org/10.1177/1042258717727718

Restrepo, L. (2016, November 17). Craft and community: The Australian women helping refugees into work. The Guardian.

https://www.theguardian.com/sustainable-business/2016/nov/17/craft-and-community-theaustralian-women-helping-refugees-into-work

Romanian-American Foundation. (2017). Ashoka - Innovators for the public. https://www.rafonline.org/programe/ashoka-innovators-for-the-public/

Smith, B. R., \& Stevens, C. E. (2010). Different types of social entrepreneurship: The role of geography and embeddedness on the measurement and scaling of social value. Entrepreneurship and Regional Development, 22(6), 575-598. https://doi.org/10.1080/08985626.2010.488405

Stevens, R., Moray, N., \& Bruneel, J. (2015). The social and economic mission of social enterprises: Dimensions, measurement, validation, and relation. Entrepreneurship Theory and Practice, 39(5), 1051-1082. https://doi.org/10.1111/etap.12091 